\title{
The Modern-Day Feminine Beauty Ideal, Mental Health, and Jungian Archetypes
}

\author{
Tetiana Danylova
}

National University of Life and Environmental Sciences of Ukraine

\begin{abstract}
Introduction: It can be argued that beauty is not only an aesthetic value, but it is also a social capital which is supported by the global beauty industry. Advertising kindly offers all kinds of ways to acquire and maintain beauty and youth that require large investments. Recent studies demonstrate that physical attractiveness guided by modern sociocultural standards is associated with a higher level of psychological well-being, social ease, assertiveness, and confidence. What is behind this pursuit of ideal beauty and eternal youth: the life-long struggle for survival, selfless love for beauty, or something else that lurks in the depths of the human unconscious?
\end{abstract}

Purpose: The aim of the paper is to analyze the modern-day feminine beauty ideal through the lens of Jungian archetypes.

Methodology: An extensive literary review of relevant articles for the period 2000-2020 was performed using PubMed and Google databases, with the following key words: "Feminine beauty ideal, body image, beauty and youth, mental health problems, C.G. Jung, archetypes of collective unconsciousness". Along with it, the author used Jung's theory of archetypes, integrative anthropological approach, and hermeneutical methodology.

Results and Discussion: Advertising and the beauty industry have a huge impact on women and their self-image. Exposure to visual media depicting idealized faces and bodies causes a negative or distorted self-image. The new globalized and homogenized beauty ideal emphasizes youth and slimness. Over the past few decades, the emphasis on this ideal has been accompanied by an increase in the level of dissatisfaction with their bodies among both women and men. Though face and body image concerns are not a mental health condition in themselves, they have a negative impact on women's mental health being associated with body dysmorphic disorder, social anxiety disorder, obsessive-compulsive disorder, panic disorder, depression, eating disorders, psychological distress, low self-esteem, self-harm, suicidal feelings. These trends are of real concern.

The interiorization of the modern standards of female beauty as the image of a young girl impedes the psychological development of women and causes disintegration disabling the interconnection of all elements of the psyche and giving rise to deep contradictions. This unattainable ideal is embodied in the Jungian archetype of the Kore. Without maturity transformations, the image of the Kore, which is so attractive to the modern world, indicates an undeveloped part of the personality. Her inability to grow up and become mature has dangerous consequences. Women "restrain their forward movement" becoming an ideal object of manipulation. Thus, they easily internalize someone's ideas about what the world should be and about their "right" place in it losing the ability to think critically and giving away power over their lives.

Conclusion: Overcoming the psychological threshold of growing up, achieving deep experience and inner growth, a woman discovers another aspect of the Kore, ceases to be an object of manipulation and accepts reality as it is, while her beauty becomes multifaceted and reflects all aspects of her true personality.

\section{Keywords}

Beauty, youth, feminine beauty ideal, body image, mental health, C.G. Jung, the Kore archetype. 
Address for correspondence:

Tetiana Danylova, Associate Professor, National University of Life and Environmental Sciences of Ukraine. e-mail: danilova tv@ukr.net

This work is licensed under a Creative Commons Attribution-

NonCommercial 4.0 International License (CC BY-NC 4.0).

\section{(c) (i) (8)}

(C) Copyright: Danylova, 2020

Licensee NDSAN (MFC- Coordinator of the NDSAN), Italy

DOI: hitp://doi.org/10.32437/mhgci.v3i1.99

\section{Introduction}

An American writer, journalist and social activist N. Wolf in her book "The Beauty Myth" debunks age-old notions of beauty as an objective and universal value. She claims that beauty is nothing more than a myth created as a means of keeping women in subjection and denies the evolutionary meaning of beauty. Nowadays, the beauty myth is associated with the institutions of power that represent the male world and is used in a counteroffensive against females: "Beauty is a currency system like the gold standard. Like any economy, it is determined by politics, and in the modern age in the West it is the last, best belief system that keeps male dominance intact. In assigning value to women in a vertical hierarchy according to a culturally imposed physical standard, it is an expression of power relations in which women must unnaturally compete for resources that men have appropriated for themselves" (Wolf, 2002, p. 12). Beauty is seen as a mere commodity. According to $\mathrm{N}$. Wolf, beauty is a fiction used by multibillion-dollar industries that create images of beauty and trade them like opium for women. Beauty takes women out of the structures of power returning them to where men prefer to see them.

The other voices are also heard in the beauty discourse. For example, a Harvard psychologist and researcher N. Etkoff in her book "Survival of the Prettiest: The Science of Beauty" (2000) argues that beauty is neither a myth, not a social construct as the representatives of the feminist movement believe, but beauty is a complex phenomenon that deeply rooted in human nature. In her opinion, this phenomenon was biologically beneficial for the preservation of homo sapiens and has eventually become an aesthetic preference. Thus, the desire for a young beauty is due to our genetic heritage.

Recent studies demonstrate that physical attractiveness guided by modern sociocultural standards is associated with a higher level of psychological well-being, social ease, assertiveness, and confidence (Datta Gupta, Etkoff \& Jaeger, 2016; Feingold, 1992; Mobius \& Rosenblat, 2006).
Submitted for publication: 07 May 2020

Received: 07 May 2020 Accepted for publication: 06 November 2020

It can be argued that beauty is not only an aesthetic value, but it is also a social capital which is supported by the global beauty industry. Advertising kindly offers all kinds of ways to acquire and maintain beauty and youth that require large investments. What is behind this pursuit of ideal beauty and eternal youth: the lifelong struggle for survival, selfless love for beauty, or something else that lurks in the depths of the human unconscious?

\section{Purpose}

The aim of the paper is to analyze the modern-day feminine beauty ideal through the lens of Jungian archetypes.

\section{Methodology}

An extensive literary review of relevant articles for the period 2000-2020 was performed using PubMed and Google databases, with the following key words: "Feminine beauty ideal, body image, beauty and youth, mental health problems, C.G. Jung, archetypes of collective unconsciousness". Along with it, the author used Jung's theory of archetypes, integrative anthropological approach, and hermeneutical methodology.

\section{Results and Discussion}

In pursuit of beauty and youth, women are ready to expose themselves to the most painful and risky procedures and purchase a thousand jars that promise to return or maintain these beauty and youth. In the contemporary world, more and more people do not want to grow old. And there is nothing new under the sun: for millennia, sages have tried to create the elixir of life or the pill of immortality. However, the combination of social, medical, cultural, and economic factors led to a surge of interest in the fight against aging in the 20th century. Maintaining the health and vitality of men, as well as the fertility and attractiveness of women became a priority after the First World War (Stark, 2020) and is especially evident today.

According to a 2017 survey, $31 \%$ of American consumers spend between $\$ 26$ and $\$ 50$ per month on cosmetics and personal care 
products, while $18 \%$ of respondents spend more than $\$ 100$ per month. The United States is home to the world's largest cosmetics and personal care market. In 2019, its value was estimated at approximately \$93.35 billion up from \$80.7 billion in 2015. Most of this market value is in the hair and skin care segments (Average amount consumers spend, 2019). Other studies show that the average woman in the US spends about $\$$ 313 a month on her looks. This is up to $\$ 3,756$ per year or $\$ 225,360$ over a lifetime (McLintock, 2020). One of the reasons women spend huge amounts of money on personal care (along with skin needs and an obsession with cosmetics) is due to social pressure.

The situation is just as serious in the beauty market of the Far East. For example, in South Korea physical beauty is associated with superiority, as far as South Korea is a country of hyper-competition for limited resources. Beautiful appearance creates a competitive advantage that helps in finding a job, choosing a partner, achieving a higher social and financial status (Luxen \& Van De Vijver, 2006). Male dominance in the East Asia region amplifies this phenomenon. Gender discrimination in South Korea has led to the objectification of women's bodies and desire to maximize social competitive advantage through risky appearance management such as cosmetic surgery (Lim, 2004). A person who has a "culturally appropriate" face and body is more likely to access social resources. This leads to the fact that women who do not meet these standards consider themselves inferior, suffer from stress, prejudice, and inequality (Kim \& Lee, 2018; Strahan et al., 2006).

Thus, unrealistic beauty standards have a huge impact on women and their self-image. Exposure to visual media depicting idealized faces and bodies causes a negative or distorted self-image (Grabe, Ward \& Hyde, 2011). The new globalized and homogenized beauty ideal emphasizes youth and slimness. Over the past few decades, the emphasis on this ideal has been accompanied by an increase in the level of dissatisfaction with their bodies among both women and men (Tiggemann, 2004).

Though face and body image concerns are not a mental health condition in themselves (Mair, 2019), they have a negative impact on women's mental health being associated with body dysmorphic disorder, social anxiety disorder, obsessive-compulsive disorder, panic disorder (Aderka et al., 2014), depression, eating disorders, psychological distress, low self-esteem, self-harm (Black, 2019; Octan, 2017), suicidal feelings. For instance, "one in eight adults in the
UK have experienced suicidal thoughts or feelings because of concerns about their body image" (Mental Health Foundation, 2019). This situation is becoming even more dangerous today, when the COVID-19 pandemic has affected those struggling with BDD (The Covid-19 Pandemic, 2020).

A philosopher and essayist $S$. Neiman in her book "Why Grow Up?: Subversive Thoughts for an Infantile Age" (2015) argues that the orientation of the modern society on youth as the main value is a disturbing symptom, since normal growing up is perceived as a decline. By focusing on consumption rather than satisfaction with work, relationships, life in general, the world creates a society of eternal adolescents. This is convenient for the establishment, which, by satisfying the material needs of people, distracts them from something else, something deeper and more important for the development of a human and humankind. The cult of youth promotes control over people who choose youth and beauty as a main life goal mainly because of the need imposed by society to meet established standards for successful social functioning.

Although evolutionary biologists argue that there are evolutionary reasons for using the images of women of the most reproductive age and men at the peak of their physical activity in advertising, S. Neiman states that the goal of humanity is not to maximize reproduction, no matter what they talk about genes. Evolutionary arguments fail to explain the enormous social emphasis on youth. Debunking the misconceptions about childhood as a state of bliss and adulthood as an evidence of painful experience, S. Neiman emphasizes that the state of maturity is an ideal that is difficult to achieve, but one must strive for it (2015).

These ideas resonate so closely with C.G. Jung's theory of the archetypes of the collective unconscious and the individuation process. Within the frame of Jungian terms, individuation means the process of achieving self-realization by bringing the individual and collective unconscious into conscious - this is the coherence of all components of the personality that unites them into the one unified integral system. C.G. Jung considered the reintegration of the personality to be a necessary condition for solving spiritual, social, ethical, and political problems of humanity. Social health depends on the health of individuals. As a psychiatrist and psychoanalyst, C.G. Jung found that his patients over the age of thirty-five were faced with the problem of reintegration with a wider spiritual reality (2017). According to the psychoanalyst,

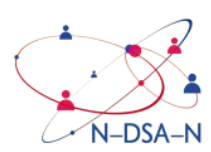


such a situation indicates that reintegration is the basis for the integrity of the psyche.

The interiorization of the modern standards of female beauty as the image of a young girl (who will never reach the age of 35) impedes the psychological development of women and leads to disintegration disabling the interconnection of all elements of the psyche and giving rise to deep contradictions. In the Jungian pantheon of archetypes, the young girl is personified by the Kore (1980). This is one of the most mysterious archetypal figures. C.G. Jung describes the Kore as an image of female innocence. The Kore belongs to the structure of the unconscious and is a part of the "impersonal psyche" common to all people. The Kore archetype has its psychological counterpart in the archetypes of the Anima and the Self: "When observed in the products of a woman's unconscious, it is an image of the supraordinate personality or self. In a man, the Kore is an aspect of the anima and partakes in all the symbolism attached to his inner personality" (Sharp, 1991). Like all psychic figures, this archetype is capable of doubling; its inseparable opposite is the archetypal Mother, with whom the Kore is equal in significance, but different in function.

Being inseparably linked with the figure of Demeter, her mother, Kore/Persephone draws socially accepted gender roles for the young women, especially in traditional cultures. "In the normal development of girls one can see the imagery of the daughter archetype unfolding in the plays, dreams and heroines which small girls may indulge in - from the early pink princess fantasy, playing with Barbie dolls, or listening to the story of the Swedish Pippi Longstocking. In the analysis of adults, images of the daughter archetype will often mediate aspects of the Self which should be made conscious and integrated in the female personality to serve the female individuation process. In so far they would tend to support the differentiation from both traditional gender roles and from identification with the anima projections from men, they support the development of ego consciousness and its growing autonomy. The differentiation between the Mother archetype and the Daughter archetype is very important for women, just like the differentiation of the anima from the mother archetype is for men" (Skogemann, undated).

Given his practical observations, C.G. Jung concludes that the Kore often appears in women in the form of an unknown young girl or nymph, maenad. The types of supraordinate personality that C.G. Jung defines as a total person are personified by Demeter and Hecate. The chthonic and nocturnal character of Hecate, which correlates with Demeter, and the fate of the Kore (Persephone) are closely related and correspond to the Triple Goddess of neopaganism, in particular Wicca (Graves, 2013). Goddess-Maiden (Cora/Persephone) is the new waxing moon, Goddess-Mother (Demeter) is the full moon, and Goddess-Crone (Hecate) is the waning moon. In the lunar cycle, these three hypostases are inextricably linked and are constantly transforming one into another (Danylova, 2020; Graves, 2013). Outside the context of eternal change, the image of the Kore is perceived differently. Youth and beauty must be preserved at any cost - such is the demand of society. This suggests that Kore will never want to transform into Demeter, and a woman, who should already be led by Demeter, will in every possible way resist the transition to the image of Hecate and cling to the image of Kore with all her might.

The tremendous striving to follow the standards of beauty imposed by society impedes the psychological development of women and leads to disintegration, which disrupts the interconnection of all elements of the psychological system and creates deep contradictions. Without maturity transformations, the image of the Kore, which is so attractive to the modern world, indicates an undeveloped part of the personality. In this regard, C.G. Jung notes: "...maidens are always doomed to die, because their exclusive domination of the feminine psyche hinders the individuation process, that is, the maturation of personality" (1980, p.190). An inability to grow up and become mature leads to dangerous consequences: "The maiden's helplessness exposes her to all sorts of dangers, for instance of being devoured by reptiles or ritually slaughtered like a beast of sacrifice. Often they are bloody, cruel, and even obscene orgies to which the innocent child falls victim" (Jung, 1980, p. 178).

Being psychologically fixated at the level of a young girl, a woman slows down her inner growth and cannot live a full life being limited to the only one role. As long as a woman is young and attractive, she may be satisfied with this role, especially if she is ready to obey the men's world because of the seeming benefits it can bring, as well as the respite from responsibility it promises (Beauvoir, 2011).

This fixation does not allow a woman to develop her potential and enjoy life as it is. She feels the consequences of this fixation on the Kore archetype in the second half of her life, when the charm of youth evaporates and cannot be maintained by any means. This is where a deep psychological crisis comes in: "... as long as

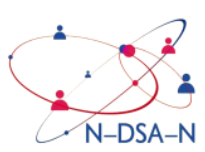


a woman is content to be a femme à homme, she has no feminine individuality. She is empty and merely glitters - a welcome vessel for masculine projections. Woman as a personality, however, is a very different thing: here illusion no longer works. So that when the question of personality arises, which is as a rule the painful fact of the second half of life, the childish form of the self disappears too" (Jung, 1980, p. 191).

In the myth, Kore/Persephone is a part of the Demeter-Kore dyad, which can symbolize wisdom and naivety respectively. By focusing on the only one side of this complex figure of the psyche, women "restrain their forward movement" becoming an ideal object of manipulation. Thus, they easily internalize someone's ideas about what the world should be and about their "right" place in it losing the ability to think critically. Being "squeezed" into the tight stereotypes of gender representations covered with an aesthetic veil and grounded by evolutionary expediency, they unconsciously give away power over their lives.

This state of the eternal girl is also supported by the men's unconscious. For him, the female figure of the Anima is not a supraordinate personality. In the products of a man's unconscious activity, Anima is manifested as the Maiden and the Mother; therefore, a man's individual interpretation always reduces this figure to his own mother or another real woman. Anima is bipolar and can appear both positive and negative. According to C.G. Jung, to the young boy, the image of the Anima manifests itself in his mother, and the same is true for infantile men: "An infantile man generally has a maternal anima; an adult man, the figure of a younger woman. The senile man finds compensation in a very young girl, or even a child" (1980, p. 192).

Due to the ambivalence of the Anima archetype, its projection can be both positive and negative, but anyhow this image is numinous that causes fear and awe associated with females (Danylova, 2015). Therefore, the projection of the Anima as a young, less experienced girl seems to a man to be safer than the image of a loving but at the same time allconsuming Mother. Evolutionary biologists associate such psychological reactions with the level of hormones and fertility of a woman without taking into account the mechanisms that dominate in the depths of our psyche. "We see the images of the Kore everywhere. Advertising loves "feminine innocence". Males and females alike get stuck on the image of the beautiful and fair girl. In Jung's terms this would reflect a regressive movement backward toward youth, rather than participation in psychic growth and transformation that leads to maturity and wisdom" (Jenna Lilla, 2013).

\section{Limitations of the study $\backslash$ Strengths of the study:}

This study has limitations as well as strengths. Lack of extensive research does not allow us to draw unambiguous conclusions. However, this theoretical study may provide an avenue for more complex, interdisciplinary research in mental health issues and ways to overcome them.

\section{Conclusion}

Overcoming the psychological threshold of growing up, achieving deep experience and inner growth, a woman can discover another aspect of Persephone/ Kore described by the psychiatrist and Jungian analyst J.S. Bolen. This is the Mistress of the Underworld with a great spiritual experience, who has lost her fear of ageing and death (Bolen, 2014). Realizing her indissoluble connection with Demeter and Hecate, this woman ceases to be an object of manipulation, accepts reality as it is, feels comfortable and confident in her own skin, while her beauty becomes multifaceted and reflects all aspects of her true personality.

\section{Conflict of interest}

The author declares no conflict of interests with regard to this study.

\section{References}

Aderka, I.M., Gutner, C.A., Lazarov, A., Hermesh, H., Hofmann, S.G., Marom, S. (2014). Body image in social anxiety disorder, obsessivecompulsive disorder, and panic disorder. Body Image, 11(1), 51-56. doi: 10.1016/j.bodyim.2013.09.002.

Average amount consumers spend on beauty and personal care products per month in the United States as of May 2017, by gender. (2019). Statista. Retrieved from https://www.statista.com/statistics/715231/aver age-monthly-spend-on-beauty-products-us/.

Beauvoir, S. (201 1). The Second Sex. Vintage.

Black, E.B., Garratt, M., Beccaria, G., Mildred, H., Kwan, M. (2019). Body image as a predictor of nonsuicidal self-injury in women: A longitudinal study. Comprehensive Psychiatry, 88, 83-89. doi:

https://doi.org/10/1016/j.comppsych.2018.11. 010. 
Bolen, J.S. (2014). Goddesses in Everywoman: Powerful Archetypes in Women's Lives. Harper paperbacks.

Danylova, T. (2015). The Way to the Self: The Novel "Steppenwolf" Through the Lens of Jungian Process of Individuation. Anthropological Measurements of Philosophical Research, 7, 28-35. https://doi.org/10.15802/ampr2015/43391

Danylova, T.V. (2020). Perceiving the Sacred Feminine: Some Thoughts on the Cycladic Figurines and Jungian Archetypes. Anthropological Measurements of Philosophical Research, 17, 88-97. https://doi.org/10.15802/ampr.v0i1 7.206719

Datta Gupta, N., Ełcoff, N.L., \& Jaeger, M.M. (2016). Beauty in Mind: The Effects of Physical Attractiveness on Psychological Well-Being and Distress. Journal of Happiness Studies, 17, 1313-1325. Retrieved from https://doi.org/10.1007/s10902-015-9644-6

Etcoff, N. (2000). Survival of the Prettiest: The Science of Beauty. Anchor.

Feingold, A. (1992). Good-looking people are not what we think. Psychological Bulletin, 111, 304-341.

Grabe, S., Ward, L. M., \& Hyde, J. S. (2011). The role of the media in body image concerns among women: A meta-analysis of experimental and correlational studies. Psychological Bulletin, 134(3), 460-476.

Graves, R. (2013). White Goddess. FSG Adult.

Jenna Lilla. (2013). On the Kore. Self-Realization. 2013.

http://deepsacred.com/2013/06/14/carl-jungimages-may-correspond-to-disturbances-andsymptoms/

Jung, C.G. (1980). The Archetypes and The Collective Unconscious. Read, H., Fordham, M., Adler, G., McGuire, W. (Eds). Bollingen Series XX. The Collected Works of C.G. Jung. Complete Digital Edition. Volume 9, Part 1. Princeton University Press. Retrieved from https://www.jungiananalysts.org.uk/wpcontent/uploads/2018/07/C.-G.-JungCollected-Works-Volume-9i_-The-Archetypesof-the-Collective-Unconscious. pdf

Jung, C.G. (2017). Modern Man in Search of a Soul. Baynes, C.F., Dell, W.S. (Trans). Martino Fine Books.

Kim, S., \& Lee, Y. (2018). Why do women want to be beautiful? A qualitative study proposing a new "human beauty values" concept. PLoS One, 13(8), e0201347.

Lim, I-S. (2004). The experience and intention of cosmetic surgery in the looks-discriminatory society. Journal of Korean Women's Studies, 20(1), 95-112.
Luxen, M.F., \& Van De Vijver F.J.R. (2006). Facial attractiveness, sexual selection, and personnel selection: When evolved preferences matter. Journal of Organizational Behavior, 27(2), $241-$ 55.

Mair, C. (2019). The influence of body image on mental health. The British Psychological Society. Retrieved from https://www.bps.org.uk/blogs/guest/influencebody-image-mental-health

McLintock, K. (2020). The Average Cost of Beauty Maintenance Could Put You Through Harvard. Byrdie. Retrieved from https://www. byrdie.com/average-cost-ofbeauty-maintenance.

Mobius, M. M., \& Rosenblat, T. S. (2006). Why beauty matters. American Economic Review, 96, 222-235.

Neiman, S. (2015). Why Grow Up?: Subversive Thoughts for an Infantile Age. Farrar, Straus and Giroux.

Octan, V. (2017). Self-Harm Behaviour in Adolescents: Body Image and Self-Esteem. Journal of Psychologists and Counsellors in Schools, 27(2), 177-189. Doi: 10.1017/jgc.2017.6.

One in eight adults in the UK have experienced suicidal thoughts or feelings because of concerns about their body image - new Mental Health Foundation survey (2019). Mental Health Foundation. Retrieved from https://www.mentalhealth.org.uk/news/oneeight-adults-uk-have-experienced-suicidalthoughts-or-feelings-because-concernsabout-their.

Sharp, D. (1991). Jung Lexicon: A Primer of Terms \& Concepts. Retrieved from https://www. psychceu.com/Jung/sharplexicon. html

Skogemann, P. (undated). The Daughter Archetype. Retrieved from https://piaskogemann.dk/\%E2\%80\%8Bthedaughter-archetype/

Stark, J.F. (2020). The Cult of Youth: Anti-Ageing in Modern Britain. Cambridge University Press.

Strahan, E.J., Wilson, A.E., Cressman, K.E., \& Buote, V.M. (2006). Comparing to perfection: How cultural norms for appearance affect social comparisons and self-image. Body Image, 3(3), $211-227$.

The Covid-19 Pandemic and Its Effect on Body Dysmorphic Disorder and Beauty Standards. (2020). Columbus Park. Eating Disorder Experts. Retrieved from https://columbuspark.com/2020/10/19/thecovid-19-pandemic-and-its-effect-on-bodydysmorphic-disorder-and-beauty-standards/ 
Tiggemann, M. (2004). Body image across the adult life span: Stability and change. Body Image, 1, 29-41.
Wolf, N. (2002). The Beauty Myth. How Images of Beauty Are Used Against Women. HarperCollins 